\title{
Anxiety of adult patients undergoing general anaesthesia and their myths and beliefs
}

\author{
Shamini Prathapan ${ }^{*}$, Lagath U Wanigabandu ${ }^{2}$, D De Silva $^{3}$, V. Serasinghe ${ }^{3}$, N. Dadigamuwa ${ }^{3}$, M. \\ Sannasuriya $^{3}$, M Rajakaruna ${ }^{3}$, Neelangani D.G.Lamahewage ${ }^{4}$ \\ Senior Lecturer ${ }^{1}$, Demonstrator ${ }^{2}$, Medical students ${ }^{3}$, Department of Community Medicine, Faculty of \\ Medical Sciences, University of Sri Jayewardenepura, Consultant Anaesthetist ${ }^{4}$, Colombo South Teaching \\ Hospital, Sri Lanka.
}

*Corresponding author: drpbshamini@yahoo.com

\begin{abstract}
Anxiety is common amongst patients awaiting general anaesthesia (GA). A descriptive cross sectional study was carried out amongst 385 patients undergoing GA at Colombo South Teaching Hospital to determine the incidence of anxiety and the associated myths, beliefs and other factors.
\end{abstract}

The results showed that $23.4 \%$ were anxious regarding GA. Females showed a higher incidence of anxiety $(35.1 \%)$ than males $(11.1 \%)$. Anxiety was higher in those with lower educational levels than higher educational levels. The highest proportion of non-anxious patients was the semiprofessionals (91.2\%). Feeling pain during surgery (25\%), getting paralyzed after anaesthesia $(23.4 \%)$ and waking up during the procedure $(12.7 \%)$ were the commonest myths and beliefs in patients. Anxiety was found to be highest among the patients who believed that their privacy would be affected during the procedure (85.7\%). Anxiety was also high among those who believed that the Anaesthetist will leave the theater $(83 \%)$ and that they may get paralyzed after the procedure $(82 \%)$. All the myths and beliefs were found to be statistically associated with the state of anxiety $(\mathrm{p}<0.05)$

It is recommend that the patients admitted to undergo GA should be counseled pre operatively about the procedure and attempts made to clear the most frequent myths and beliefs.

Keywords: pre operative anxiety; myths; beliefs

\section{Introduction}

The need to evaluate and prevent pre-operative anxiety in patients is of utmost priority. Contributing factors maybe fears regarding GA, patient's myths and beliefs and other socio demographic and individual factors ${ }^{1-4}$.

Anxiety in patients awaiting surgery can have deleterious effects such as fluctuations in blood pressure, respiratory rate, heart rate, etc. and poor post operative healing.

There are various scales that can be used to measure anxiety. Depression, Anxiety and Stress Scale (DASS), STAI (State-Trait Anxiety Inventory questionnaire) are a few. However more recently the Amsterdam Preoperative Anxiety and Information Scale (APAIS) were designed specifically for pre-operative anxiety and were validated and is currently used by many ${ }^{5,6}$.

There are no similar studies done in Sri Lanka. Thus we aimed to describe the extent of anxiety and to describe the myths and beliefs and socio demographic factors associated with patients undergoing GA at Colombo South Teaching Hospital, Sri Lanka, which would help the doctors focus better on pre operative counseling. This would help to reduce morbidity and improve the quality of care.

\section{Methodology}

A descriptive cross sectional study was carried out in surgical, ear nose throat, orthopaedic and gynaecology wards at the Colombo South 
Teaching Hospital. Study population was all patients who were awaiting GA within 24 hours. The paediatric, critically ill, mentally retarded, dumb patients and patients unable to communicate in Sinhala or English were excluded. The expected proportion of anxiety was taken as $50 \%$ and with 0.05 precision a sample size of 384 was obtained. Systematic sampling method was used to recruit from the wards, where every other patient in the above wards awaiting surgery was recruited. The study instrument was an interviewer administered questionnaire. It has two parts: The Amsterdam Preoperative Anxiety and Information Scale (APAIS), which was modified and used to determine the extent of anxiety in patients awaiting GA and an interviewer administered questionnaire which was used to determine the myths and beliefs. The questionnaire was developed with the help of literature. Once developed judgmental validity of the questionnaire was ensured with experts in this field. This was translated to Sinhala and Tamil. A pilot study was done at the Sri Jayewardenepura Hospital and necessary changes were made to the questionnaire. Each researcher carried out the data collection by him/herself with the patient. Data was entered and analysed on SPSS version 15.0. Significance level was considered as less than 0.05 . Ethical clearance was obtained from the Ethics Committees of the Faculty of Medical Sciences, University of Sri Jayewardenepura and the Colombo South Teaching Hospital.

\section{Results}

Among the 385 patients, 90 (23.4\%) patients were anxious. Significantly, larger numbers of female patients were anxious (Table 1). A statistically significant difference was not observed between the anxiety state and age groups (Table 2). Compared to patients belonging to other religious faiths, $45.7 \%$ following Islam were anxious but the difference was not statistically significant (Table 3). Patients who have not attended school $(53.8 \%)$ and those who have studied up to grade 5 or less $(56.5 \%)$ showed the most amount of anxiety (Table 4). The least anxious were those patients in semiprofessional occupations $(8.8 \%)$ (Table 4).
Table 1 Frequency distribution of anxiety among males and females

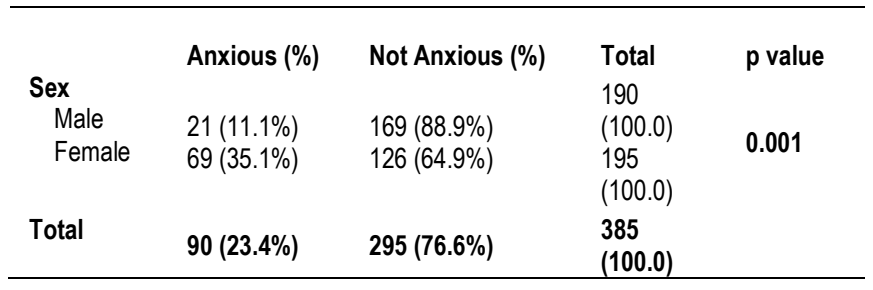

Table 2 Frequency distribution of anxiety among different age groups

\begin{tabular}{lllll} 
& Anxious (\%) & $\begin{array}{l}\text { Not Anxious } \\
(\%)\end{array}$ & Total & $\begin{array}{l}\mathbf{p} \\
\text { value }\end{array}$ \\
$\begin{array}{c}\text { Age } \\
12-39 \text { years }\end{array}$ & $12(13.5 \%)$ & $77(86.5 \%)$ & $89(100.0)$ & \\
$40-59$ years & $66(26.0 \%)$ & $188(74.0 \%)$ & $254100.0)$ & $\mathbf{2}$ \\
$60-79$ years & $12(28.6 \%)$ & $30(71.4 \%)$ & $42(100.0)$ & \\
& & & & \\
Total & $\mathbf{9 0 ( 2 3 . 4 \% )}$ & $\mathbf{2 9 5 ( 7 6 . 6 \% )}$ & $\mathbf{3 8 5 ( 1 0 0 . 0 )}$ & \\
\hline
\end{tabular}

Table 3 Frequency distribution of anxiety and religious groups

\begin{tabular}{lllll}
\hline & Anxious (\%) & Not Anxious (\%) & Total & p value \\
Religion & & & 293 & \\
Buddhist & $63(21.5 \%)$ & $230(78.5 \%)$ & $(100.0)$ & \\
Islam & $16(45.7 \%)$ & $19(54.3 \%)$ & $35(100.0)$ & 0.06 \\
Hindu & $6(21.4 \%)$ & $22(78.6 \%)$ & $28(100.0)$ & \\
Catholic & $5(17.2 \%)$ & $24(82.8 \%)$ & $29(100.0)$ & \\
Total & & & 385 & \\
& $90(23.4 \%)$ & $295(\mathbf{7 6 . 6 \% )}$ & $(\mathbf{1 0 0 . 0 )}$ & \\
\hline
\end{tabular}

Table 4 Frequency distribution of educational level and occupation and anxiety

\begin{tabular}{|c|c|c|c|c|}
\hline & $\begin{array}{l}\text { Anxious (\%) } \\
(n=90)\end{array}$ & $\begin{array}{l}\text { Not } \\
\text { Anxious } \\
(\%) \\
(n=295)\end{array}$ & Total & $\begin{array}{l}p \\
\text { value }\end{array}$ \\
\hline \multicolumn{5}{|l|}{ Education } \\
\hline $\begin{array}{l}\text { No schooling } \\
\text { Less than grade } 5 \\
\text { Up to } \mathrm{O} / \mathrm{L} \\
\text { Up to } \mathrm{A} / \mathrm{L} \\
\text { Graduate }\end{array}$ & $\begin{array}{l}7(53.8 \%) \\
35(56.5 \%) \\
34(21.4 \%) \\
13(11.4 \%) \\
1(2.7 \%)\end{array}$ & $\begin{array}{l}6(46.2 \%) \\
27(43.5 \%) \\
125(78.6 \%) \\
101(88.6 \%) \\
36(97.3 \%)\end{array}$ & $\begin{array}{l}13(100.0) \\
62(100.0) \\
159(100.0) \\
124(100.0) \\
37(100.0)\end{array}$ & 0.001 \\
\hline \multicolumn{5}{|l|}{ Occupation } \\
\hline $\begin{array}{l}\text { Professional } \\
\text { Semi Professional } \\
\text { Lesser professional } \\
\text { Skilled } \\
\text { Unskilled }\end{array}$ & $\begin{array}{l}1(25.0 \%) \\
5(8.8 \%) \\
23(20.4 \%) \\
14(20.3 \%) \\
47(38.5 \%)\end{array}$ & $\begin{array}{l}3(75.0 \%) \\
52(91.2 \%) \\
90(79.4 \%) \\
55(79.7 \%) \\
75(61.5 \%)\end{array}$ & $\begin{array}{l}4(100.0) \\
57(100.0) \\
113(100.0) \\
69(100.0) \\
122(100.0)\end{array}$ & 0.001 \\
\hline
\end{tabular}


Table 5 Anxiety status among patients with myths and beliefs

\begin{tabular}{|c|c|c|c|c|}
\hline Myths & $\begin{array}{l}\text { Patients } \\
\text { with } \\
\text { Myths (\%) } \\
(\mathrm{n}=385)\end{array}$ & $\begin{array}{l}\text { Anxiety } \\
(\%)\end{array}$ & $\begin{array}{l}\text { No } \\
\text { Anxiety } \\
(\%)\end{array}$ & $\begin{array}{l}\mathrm{p} \\
\text { value }\end{array}$ \\
\hline Waking up during GA & $49(12.7)$ & $\begin{array}{l}35 \\
(71.4)\end{array}$ & $\begin{array}{l}14 \\
(28.6)\end{array}$ & 0.001 \\
\hline Hearing noises from surrounding & $13(3.4)$ & $7(53.8)$ & $6(46.2)$ & 0.015 \\
\hline Seeing things in the surrounding & $26(6.7)$ & $\begin{array}{l}19 \\
(73.1)\end{array}$ & $7(26.9)$ & 0.001 \\
\hline $\begin{array}{l}\text { Feel pain during the anaesthetic } \\
\text { procedure }\end{array}$ & $94(24.4)$ & $\begin{array}{l}65 \\
(69.1)\end{array}$ & $\begin{array}{l}29 \\
(30.9)\end{array}$ & 0.001 \\
\hline Privacy affected during anaesthesia & $21(5.5)$ & $\begin{array}{l}18 \\
(85.7)\end{array}$ & $3(14.3)$ & 0.001 \\
\hline Fail to wake up after surgery & $71(18.4)$ & $\begin{array}{l}53 \\
(74.6)\end{array}$ & $\begin{array}{l}18 \\
(25.4)\end{array}$ & 0.001 \\
\hline $\begin{array}{l}\text { Getting paralyzed after undergoing } \\
\text { GA }\end{array}$ & $90(23.4)$ & $\begin{array}{l}74 \\
(82.2)\end{array}$ & $\begin{array}{l}16 \\
(17.8)\end{array}$ & 0.001 \\
\hline Anaesthetist will leave the theater & $6(1.5)$ & $5(83.3)$ & $1(16.7)$ & 0.003 \\
\hline Given blood without consent & $10(2.6)$ & $7(70.0)$ & $3(30.0)$ & 0.002 \\
\hline Addicted to pain medication & $37(9.6)$ & $\begin{array}{l}26 \\
(70.3)\end{array}$ & $11(29.7)$ & 0.001 \\
\hline
\end{tabular}

The commonest myth the patients had was of feeling pain during the procedure. $71.4 \%$ of the patients who thought they will wake up during anaesthesia were anxious and $82.2 \%$ of the patients who were of the belief that they would get paralyzed after the procedure were anxious. Eighteen (85.7\%) patients were anxious that their privacy would be affected during anaesthesia. Other than for one patient (16.7\%), among the six patients who had the belief that the Anaesthetist will leave the theater, five patients $(83.3 \%)$ were anxious. All the myths and beliefs were found to be statistically associated with the state of anxiety.

\section{Discussion}

In this study, using the APAIS, $23.4 \%$ were anxious. Similar results were seen from another study, where $38.3 \%$ patients were anxious ${ }^{7}$, whereas a Mexican study showed a much higher incidence $(76 \%)^{8}$. The reason for the lower proportion of anxiety in this study could be due to the culture and attitudes of the Sri Lankan population in trusting the doctors ${ }^{9}$. A study in Iran compared the level of anxiety of passengers flying and patients receiving anaesthesia. Anxiety in passengers was significantly less when compared with the pre operative anaesthetic group ${ }^{10}$.

Bearing myths and beliefs about general anaesthesia is a predisposing factor for anxiety. A survey after day surgery in UK, revealed that dying while asleep (25\%) and waking up during surgery (20\%), were some concerns that made patients very anxious. ${ }^{11}$ In our study among the patients who thought that they will not wake up after the surgery nearly $75 \%$ were anxious. The number of patients who thought that they would hear noises were low $(n=13)$, however, $54 \%$ were anxious of that belief. These rates were higher compared to the UK study. Similar results were shown in a larger study in UK, where they concluded that alleviating misconceptions would greatly reduce anxiety ${ }^{12}$.

Among patients who believed that the anaesthetist would leave the patient after administering GA, majority were anxious (83.3\%). Among the patients who believed that they would be given blood without their consent, $70 \%$ were anxious. It is thus evident that patients with myths and beliefs are more anxious than those without. This could be remedied by adequate and timely information given during the pre operative visit. A study found that patients receiving better pre-anesthetic information from the anaesthesiologist showed reduced rates of anxiety compared to those who had not had any information ${ }^{13}$.

Many studies have found that the socio demographic factors too influence preoperative anxiety. A study found that females have five times higher risk than males ${ }^{5,14,15}$. Our study too showed a statistically significant association between anxiety and sex. Further the education level which also reflects the occupation showed that there is an association with the level of anxiety. Therefore it is of utmost priority that preoperative counseling should be further streamlined to the sex and the patients' educational background or the profession.

One of the limitations in this study was that the paediatric group and their parents were excluded. The patients were also not stratified into undergoing major or minor surgery which could have affected the results. We have also not measured the time nor described the counseling procedure. This could be a draw back in the counseling procedure as a study in Mexico, shows the time an anaesthetist spends with a patient 
before anaesthesia, is not enough to get the patient prepared for anaesthesia and surgery ${ }^{8}$.

In conclusion, anaesthetic procedure generates anxiety, and thus attention should be focused to reduce anxiety, mainly to reduce post operative pain and complications. Thus pre operative streamlined efficient health education and appropriate psychological counseling is of utmost priority.

\section{References}

1. Markland D, Hardy L. Anxiety, relaxation and anaesthesia for day-case surgery. British Journal of Clinical Psychology 1993;32:493-504. http://dx.doi.org/10.1111/j.2044-8260.1993.tb01085.x 2. Ruiz-López E, Mu-oz-Cuevas JH, Olivero-Vásquez YI, Islas-Saucillo M. Preoperatory anxiety at the General Hospital of Mexico. Revista Meidica del Hospital General de Mexico 2000; 63:231-236.

3. Anderson KO, Masur FT. Psychological preparation for invasive medical and dental procedures. Journal of Behavioral Medicine 1983;6:1-40. http://dx.doi.org/10.1007/BF00845274

4. Thomas V, Heath M, Rose D, Flory P. Psychological characteristics and the effectiveness of patientcontrolled analgesia. British Journal of Anaesthesia 1995;74:271-276.

http://dx.doi.org/10.1093/bja/74.3.271. PMid:7718370

5. Moerman N, Van Dam F, Muller M. The Amsterdam Preoperative Anxiety and Information Scale (APAIS). Anesthesia and Analgesia 1996;82:445-451. PMid:8623940

6. Oosting H, Maranets I, Kain ZN. Preoperative anxiety and intraoperative anesthetic requirements. Anesthesia and Analgesia 1999;89:1346-1351.

7. Jawaid M, Mushtaq A, Mukhtar S, Khan Z. Preoperative anxiety before elective surgery. Neurosciences Journal 2007; 12 (2) : 145 -148.

8. Millán JV, Serrano JRB, Aguirre JMO. Anxiety in preoperative anesthetic procedures. Cirugia Cirujanos Journal 2010; 78(2): 147 -151

9. Russell S, Treatment-seeking behaviour in urban Sri Lanka: Trusting the state, trusting private providers. Social Science \& Medicine 2005:61(7): 1396-1407 http://dx.doi.org/10.1016/j.socscimed.2004.11.077

PMid:16005775

10. Kamalipour H, Mahmoudi H. The relief of anxiety: comparative study- air plane flying vs anesthesia. Middle East Journal of Anaesthesiology 2003; 17 (3) :427 - 434.

11. Shevde K, Panagopoulos G, A Survey of 800 patients' knowledge, attitudes, and concerns regarding anesthesia. Anesthesia and Analgesia 1991;73:190 -8. http://dx.doi.org/10.1213/00000539-199108000-00013. PMid:1854034

12. Mitchell M. General anaesthesia and day-case patient anxiety. Journal of Advanced Nursing 2010; 66 (5):1059-71

http://dx.doi.org/10.1111/j.1365-2648.2010.05266.x

PMid:20337788

13. Kiyohara LY, Kayano LK, Oliveira LM, Yamamoto MU, Inagaki MM, Ogawa NY, et al. Surgery information reduces anxiety in the pre-operative period. Revista do Hospital das Clinicas 2004;59:51-56. http://dx.doi.org/10.1590/S0041-87812004000200001 PMid:15122417

14. Wiens AG. Preoperative anxiety in women. Association of peri operative registered Nurses AORN Journal1998;68(1):74-7,79-81,83-8.

http://www.sciencedirect.com/science/article/pii/S0001 $\underline{209206627166}$

15.Domar AD, Everett LL, Keller MG. Preoperative anxiety: Is it a predictable entity. Anesthesia \& Analgesia 1989;69(6):763-767.

http://dx.doi.org/10.1213/00000539-198912000-00013

PMid:2589657 